\title{
Efficacy of edible oils in the control of pulse beetle, Callosobruchus chinensis L. in stored pigeonpea
}

\author{
M. Khalequzzaman*, Shah Hussain Ahmad Mahdi and S. H. M. Osman Goni \\ Department of Zoology, University of Rajshahi, Rajshahi-6205, Bangladesh.
}

\begin{abstract}
Seven vegetable oils viz., sunflower (Heliunthus annus, L.), mustard (Brassica juncea Cross ), groundnut (Arachis hypogaea, L.), sesame (Sesamum indicum L.), soybean [Glycine max L. (Merril)], olive (Olea europea) and oil palm (Elaeis guineensis W. J. Jacquin), each were applied at the rates of 5, 7.5, and $10 \mathrm{ml} . \mathrm{kg}-1$ of grain $(0.5,0.75$ and $1 \% \mathrm{v} / \mathrm{w}$ concentrations) as grain protectants of pigeonpea against the pulse beetles (Callosobruchus chinensis L.). Effects on progeny emergence, loss in grain weight, and germination up to 66 days after treatment were measured. Adult emergence was completely prevented and the minimum grain loss was achieved by groundnut oil at $1 \%$ up to 66 days after treatment. Since treatments with groundnut and palm oils at $5 \mathrm{ml} . \mathrm{kg}-1$ showed high acceptability by consumers, it can be recommended for $C$. chinensis control in stored pigeonpea for approximately two months.
\end{abstract}

Key Words: Vegetable oils, Callosobruchus, pigeonpea, progeny emergence, grain protectant

\section{Introduction}

Pigeonpea or red gram (Cajanus cajan L.) is an important pulse crop in Bangladesh and is the main source of protein for vegetarians. The pulse seeds suffer a great damage during storage due to insect attack (Sherma, 1989). Among the insect pests attacking stored products the pulse beetle Callosobruchus chinensis L. (Coleoptera: Bruchidae) is a serious one. This insect has been reported from the Philippines, Japan, Indonesia, Sri Lanka, Burma and India. It is a notorious pest of chickpea, mung, motor, peas, cowpeas, lentil and arhar (Aslam et al., 2002). Pulse beetle being an internal feeder cannot be controlled with insecticides. It is also not advisable to mix insecticides with food grains. Fumigation being the most effective method cannot be practiced in our villages because the storage structures are not airtight and these are are mostly built inside the residential areas. Plant materials which are being traditionally used by some farmers are quite safe and appear to be the most promising grain protectants (Al-Lawati et al., 2002a,b).

Research on oils as protectants has been conducted on Sitophilus species and stored-product Lepidoptera (Koona \& Njoya, 2004). Vegetable oils and plant products have been used for a long time for the protection of stored grains. But a very little work on the storage of pigeonpea seeds using vegetable oils has been carried out. Mummigatti \& Raghunathan (1977), Singh et al., (1978), Varma \& Pandey (1978), and Ali et al., (1983) tried different vegetable oils against pulse beetle on green gram (Pluseolus aureus Roxb.), black gram (P. mungo var. radiutus L.), and cowpea (Vigna sinensis Savi.). Khaire et al. (1993) reported the effectiveness of vegetable oils against $C$. chinensis on pigeonpea.

C. maculatus (F.) attacking Vigna species was also tested against several oils. Pandey et al. (1981), Santos et al. (1981), Messina \& Renwick (1983) Pierrard (1986) and Ahmed et al. (1988) used oils of groundnut (Arachis hypogaea L.), castor (Ricinus communis L.), coconut, palm kernel, corn, cotton, babassu (Orbignya sp.), mustard (Brassica juncea L.), olive (Olea europea), sesame (Sesamum indicum L.), sunflower (Heliunthus annuus L.), and rice (Oryza sativa L.) in their studies. There were differences in efficacy at the doses of oil tested under different experimental conditions, as noted by Pierrard (1986). Castor oil at 8 mg. $\mathrm{kg}^{-1}$ provided complete protection against $C$. maculutus (Singh et al., 1978).

For the protection of stored chick-peas, Cicer arietinum L., against C. chinensis, the application of mustard oil at $10 \mathrm{ml} . \mathrm{kg}^{-1}$ was effective for 5 months of storage and did not affect seed germination. But this oil did not impart protection to seeds and caused complete inhibition of germination (Khalique et al., 1988). Palm and coconut oils at $4 \mathrm{ml} . \mathrm{kg}^{-1}$ were the most effective protectants of chick-pea seeds against $C$. chinensis for 3 months of storage, followed by groundnut, rapeseed and mustard oils. Sesame, sunflower and soybean oils were considered inferior to the others (Singh et al., 1990). Neem seed oil showed $100 \%$ control of C. chinensis for 5 months when applied at $10 \mathrm{ml} \cdot \mathrm{kg}^{-1}$ (Das, 1987). In view of the encouraging results obtained by the above workers, the effectiveness of these and other vegetable oils were estimated against C. chinensis infesting pigeonpea seeds in respect of emergence of progeny adults, loss of grain weight, and seed germination. 


\section{Materials and Methods}

Mass culture of $C$. chinensis was maintained using the procedure described by Strong et al. (1968). Edible oils of sunflower (Heliunthus annus, L. ), mustard (Brassica juncea Coss ), groundnut (Arachis hypogaea, L.), sesame (Sesamum indicum L.), soybean [Glycine max L. (Merril)], olive (Olea europea) and oil palm (Elaeis guineensis W. J. Jacquin) were applied at 5, 7.5 , and $10 \mathrm{ml} . \mathrm{kg}^{-1}$ of pigeonpea seed $(0.5,0.75$, and $1 \% \mathrm{v} / \mathrm{w}$ concentrations). Samples of $600 \mathrm{~g}$ of healthy pigeonpea seeds were treated with known amounts of the oils. The requisite quantities of each oil were dissolved in $24 \mathrm{ml}$ of petroleum ether and the treated sample was shaken slowly for 15 min on a mechanical shaker in a ground glass-stoppered conical flask. A stock of the pigeonpea seed treated with the oils was stored in perforated polythene bags.

Samples each of $10 \mathrm{~g}$ were drawn at intervals of 33 and 66 days and kept in small glass vials $(7.5 \times 2.5 \mathrm{~cm})$. Three replications were used. Three pairs of 0 -1 day-old adults of $C$. chinensis were introduced into each vial, covered with muslin cloth and secured firmly with rubber bands. Dead beetles were removed 12 days after release when almost all parental beetles were found dead in all treatments. Emergence of adult progeny was recorded daily for a period of 20 days and the adults removed every 2-3 days to avoid the next generation. The percentage loss in grain weight was recorded at 33 and 66 days after release of beetles, i.e. after completion of emergence of the adult progeny. Seed germination was tested after 66 days treatment. The experiments were conducted at room temperatures ranging from $27^{\circ}$ to $35^{\circ} \mathrm{C}$ with $50-80 \%$ relative humidity.

\section{Results and Discussion}

The average percentage of adults that had emerged at 33 days after treatment ranged from 1 to 49.33 in different treatments. Significantly lower numbers of progeny were observed in all treatments when compared with untreated control (77.00\%). Fewer adults emerged from seeds treated with groundnut oil at all concentrations to show highest activity among the oils used in this investigation. At 66 days after treatment, the percentage of adult progeny ranged from 5.35 to 98.66 against 96.00 in control. In all treated oils the percentage of progeny emerged differed significantly between 33 and 66 days of storage (Table 1). Among different oil treatments percentage of progeny emerged also differ significantly at storage period of 33 days $\left(\mathrm{F}_{6,12}=34.54\right.$, $\left.\mathrm{LSD}=8.55, \mathrm{P}<0.01\right)$ and 66 days $\left(\mathrm{F}_{6,12}=10.02\right.$, $\left.\mathrm{LSD}=24.23, \mathrm{P}<0.01\right)$

The average percentage of loss in grain weight after 33 days of treatment ranged from 0.6 to 6.9 in different treatments against $14.00 \%$ in control. Treatments with palm and groundnut oils at $1 \%$ appeared to be promising showing comparatively lower weight loss of grains. At 66 days after treatment, the average percentage loss in grain weight ranged from 0.9 to 16.9 in different treatments and in control it was 19.8\%. Here t-values showed that statistical difference between storage periods occurred only sunflower $(\mathrm{P}<0.001)$ and sesame $(\mathrm{P}<0.05)$ oils. But the differences among treated oils are insignificant in both storage periods $\left(\mathrm{F}_{6,12}=2.71\right.$ for 33 days and $\mathrm{F}_{6,12}=$ 1.70 for 66 days).

Considering the efficacy of different vegetable oils on the basis of various criteria, all the oils under study appeared to be promising as grain protectants. For $C$. chinensis, control in $V$. unguiculata (L.), purified oils of soybean and corn, and crude corn oil showed efficacy at 5,10 and $15 \mathrm{~g} \cdot \mathrm{kg}^{-1}$ for 8 months (Cruz \& Cardona, 1981). Castor oil on V. radiata (L.) seeds at $10 \mathrm{ml} . \mathrm{kg}^{-1}$ provided complete control of C. chinensis for 18 months without affecting seed viability (Babu et al., 1989). Mummigatti \& Ranghunathan (1977) reported that oils of castor, groundnut, and mustard inhibited the multiplication of $C$. chinensis.

Khaire et al. (1992) studied efficacy of ten vegetable oils viz. sunflower, castor, mustard, safflower, palm, groundnut, sesame, neam, karanj and maize each applied at rates of $5,7.5$ and $10 \mathrm{ml}^{-\mathrm{kg}^{-1}}$ of grain $(0.5$, 0.75 and $1 \% \mathrm{v} / \mathrm{w}$ concentration) as grain protectants of pigeon pea against $C$. chinensis. Effects on progeny emergence, loss in grain weight and germination upto 100 days after treatment were measured. Adult emergence was completely prevented by karanj oil at 0.75 and $1 \%$ and neem oil at all levels up to 100 days. No emergence of adults occurred up to 66 days with castor oil at 0.75 and $1 \%$ levels. Minimum grain loss was noted with castor, mustard and groundnut oils at the $1 \%$ level up to 100 days after treatment. Ahmed et al. (2003) used neem and sesame oil and found both oils can control the larvae of $C$. chinensis inside the cotyledons of azuki beans. Swella \& Mushobozy (2007) observed that coconut oil provided the best protection of the natural products against $C$. maculatus. In the present study only edible oils were used and groundnut oil provided the best protection followed by oil palm against $C$. chinensis.

The mode of action of oils is partially attributed to interference in normal respiration, resulting in suffocation (Schoonhoven, 1978). However, factors other than oxygen starvation probably also play a role in their mode of action (Shaaya \& Ikan, 1978). Egg mortality has been attributed to toxic components and also to physical properties, which cause changes in surface tension and oxygen tension within the egg (Singh et al., 1978). It is also thought that oils exert some lethal action on developing embryos or firstinstar larvae, for example, by the reduction in rate of 
gaseous exchange due to a "barrier" effect and/or direct toxicity by penetrated oil fractions (Don Pedro, 1989). Since treatments with groundnut and palm oils at ml. $\mathrm{kg}^{-1}$ preserved desirable characteristics, the dose can be recommended for suppressing $C$. chinensis in stored pigeonpea for approximately two months.

Table 1. Effect of edible oils on emergence of adult progeny of $C$. chinensis and loss in weight of pigeonpea

\begin{tabular}{|c|c|c|c|c|c|}
\hline \multirow{2}{*}{ Oils } & \multirow{2}{*}{$\begin{array}{l}\text { Dose of oil } \\
\left(\mathrm{ml} . \mathrm{kg}^{-1}\right)\end{array}$} & \multicolumn{2}{|c|}{ Progeny emerged (\%) } & \multicolumn{2}{|c|}{ Grain loss (\%) } \\
\hline & & 33 days & 66 days & 33 days & 66 days \\
\hline \multirow{4}{*}{ Sunflower } & 0.50 & 44.00ef & 66.33defg & 1.9 & 10.1 \\
\hline & 0.75 & 43.00def & 74.66ef & 3.6 & 10.8 \\
\hline & 1.00 & 37.66de & 68.66def & 3.7 & 9.00 \\
\hline & t-values & \multicolumn{2}{|c|}{$8.94 * * *$} & \multicolumn{2}{|c|}{$8.79 * * *$} \\
\hline \multirow{4}{*}{ Mustard } & 0.50 & 7.66a & 92.00hi & 2.1 & 6.80 \\
\hline & 0.75 & $10.00 \mathrm{ab}$ & 88.00ghi & 4.2 & 11.0 \\
\hline & 1.00 & $10.00 \mathrm{ab}$ & 78.93efghi & 3.2 & 0.70 \\
\hline & t-values & \multicolumn{2}{|c|}{$19.94^{* * *}$} & \multicolumn{2}{|c|}{$0.98 \mathrm{~ns}$} \\
\hline \multirow{4}{*}{ Groundnut } & 0.50 & $8.33 a$ & 24.66ab & 1.3 & 1.10 \\
\hline & 0.75 & $8.00 \mathrm{a}$ & 28.66ab & 0.8 & 4.60 \\
\hline & 1.00 & $1.00 \mathrm{a}$ & $5.35 \mathrm{a}$ & 1.5 & 0.80 \\
\hline & t-values & \multicolumn{2}{|c|}{$1.81 \mathrm{~ns}$} & \multicolumn{2}{|c|}{$0.78 \mathrm{~ns}$} \\
\hline \multirow{4}{*}{ Sesame } & 0.50 & $24.00 \mathrm{c}$ & 49.00bcd & 1.6 & 11.3 \\
\hline & 0.75 & $11.33 b$ & 64.33defg & 0.1 & 11.1 \\
\hline & 1.00 & $16.66 \mathrm{~b}$ & 68.66defg & 7.6 & 9.80 \\
\hline & t stat & \multicolumn{2}{|c|}{$6.19 * *$} & \multicolumn{2}{|c|}{$3.26^{*}$} \\
\hline \multirow{4}{*}{ Soya bean } & 0.50 & 39.66de & $98.66 \mathrm{i}$ & 6.8 & 16.9 \\
\hline & 0.75 & $35.00 \mathrm{~d}$ & 75.66efg & 4.6 & 12.2 \\
\hline & 1.00 & $49.33 f$ & $97.33 \mathrm{i}$ & 6.6 & 1.00 \\
\hline & t-values & \multicolumn{2}{|c|}{$5.75^{* *}$} & \multicolumn{2}{|c|}{$0.84 \mathrm{~ns}$} \\
\hline \multirow{4}{*}{ Olive } & 0.50 & 14.00b & 73.66efg & 1.4 & 6.80 \\
\hline & 0.75 & $14.00 \mathrm{~b}$ & 48.00bcd & 6.9 & 1.30 \\
\hline & 1.00 & $10.33 b$ & 62.33cdef & 5.4 & 6.00 \\
\hline & t-values & \multicolumn{2}{|c|}{$6.45^{* *}$} & \multicolumn{2}{|c|}{$0.06 \mathrm{~ns}$} \\
\hline \multirow{4}{*}{ Oil Palm } & 0.50 & $12.66 \mathrm{~b}$ & 81.66fghi & 1.0 & 0.90 \\
\hline & 0.75 & $10.33 b$ & 55.66cde & 0.6 & 3.00 \\
\hline & 1.00 & $6.67 \mathrm{~b}$ & 37.33bc & 0.6 & 10.0 \\
\hline & t-values & \multicolumn{2}{|c|}{$3.72 *$} & \multicolumn{2}{|c|}{$1.42 \mathrm{~ns}$} \\
\hline Untreated & - & 77.00 & 96.00 & 14.0 & 19.8 \\
\hline
\end{tabular}

\section{References}

Ahmed, K., Khalique, F., Afzal, M., Malik, B. A. \& Malik, M. R. 1988. Efficacy of vegetable oils for protection of greengram from attack of bruchid beetle. Pakistan J. Agric. Res. 9: 413-416.

Ahmed, K.S., Itino, T. \& Ichikawa, T. 2003. Duration of developmental stages of Callosobruchus chinensis L. (Coleoptera:Bruchidae) on azuki bean and the effects of neem and sesame oils at different stages of their development. Pak. J. Biol. Sci. 6: 932-935.

Ali, S. I., Singh, O. P. \& Misra, U. S. 1983. Effectiveness of plant oils against pulse beetle Callosobruchus chinensis Linn. Indian J. Entomol. 45: 6-9.

Al-Lawati, H. T., Azam, K. M. \& Deadman M. L. 2002a. Insecticidal and Repellent Properties of Subtropical Plant Extracts Against Pulse Beetle, Callosobruchus chinensis. Agric. Sci. 7: 37-45.
Al-Lawati, H. T., Azam, K. M. \& Deadman M. L. 2002b. Potential of Omani Flora as Source of Natural Products for Control of Pulse Beetle, Callosobruchus chinensis. Agric. Sci. 7:59-63.

Aslam, M., Khan, K. A. \& Bajwa, M. Z. H. 2002. Potency of Some Spices Against Callosobruchus chinensis Linnaeus. J. Biol. Sci. 2: 449-452.

Babu, T. R., Reddy, V. S. \& Hussaini, S. H. 1989. Effect of edible and non edible oils on the development of the pulses beetle Callosobruchus chinensis (L) and on viability and yield of mungbean (Vigna radiata (L) Wilczek). Trop. Sci. 29: 215-220.

Cruz, C. \& Cardona, E. 1981. Control of dry seed weevils with cooking oil. J. Agric. Univ. Puerto Rico: 295-298.

Das, G. P. 1987. Efficacy of neem oil on the egg grub mortality of Callosobruchus chinensis Linn. (Bruchidae: Coleoptera). Trop. Grain Leg. Bull. 34: 14-15.

Don Pedro, K. N. 1989. Mechanisms of action of some vegetable oils against Sitophilus zeamais Motsch. (Coleoptera: Curculionidae) on wheat. J. Stored Prod. Res. 25: 217-223.

Khaire, V. M., Kachare, B. V. \& Mote, U. N. 1992. Efficacy of different vagetable oils as grain protectants against pulse beetle, Callosobruchus chinensis L. in incresing storablity of pigeon pea. J. Stored Prod. Res. 28: 153-156.

Khaire, V. M., Kachare, B. V. \& Mote, U. N. 1993. Effect of different vegetable oils on ovipositional preference and egg hatching of Callosobruchus chinensis Linn. on pigeonpea seeds. Seed Res. J. 21: 128-130.

Khalique, F., Ahmed, K., Afzal, M., Malik, B. A. \& Riaz, M. 1988. Protection on stored chickpea, Cicer arietinum L. from attack of Callosobruchus chinensis L. (Coleoptera: Bruchidae). Trop. Pest Manag. 34: 333-334.

Koona, P. \& Njoya, J. 2004. Effectiveness of soybean oil and powder from leaves of Lantana camara Linn. (Verbenaceae) as protectants of stored maize against infestation by Sitophilus zeamais Motsch. (Coleoptera: Curculionidae). Pak. J. Biol. Sci. 7: 2125-2129.

Messina, F. J. \& Renwick, J. A. A. 1983. Effectiveness of oils in protecting stored cowpea from the cowpea weevil (Coleoptera: Bruchidae). J. Econ. Entomol. 76: 634-636.

Mummigatti, S. G. \& Raghunathan, A. N. 1977. Inhibition of multiplication of C. chinensis (L.) by vegetable oils. J. Food Sci. Tech. 14: 184-185. 
Pandey, G. P., Doharey, R. B. \& Varma, B. K. 1981. Efficacy of some vegetable oils for protecting greengram against the attack of Callosobruchus maculatus (Fabr.). Indian J. Agric. Sci. 51: 910-912.

Pierrard, G. 1986. Control of the cowpea weevil, Callosobruchus maculatus, at the farmer level in Senegal. Trop. Pest Manage. 32: 197-200.

Santos, J. H. R., Beleza, M. G. S. \& Silva, N. L. 1981. Amortalidade do Callosobruchus maculatus em grHos de Vignasinensis, tratados corn oleo de algodlo. Cienc. Agron. 12: 45-48.

Schoonhoven, A. V. 1978. The use of vegetable oils to protect stored beans from bruchid attack. J. Econ. Entomol. 71: 254-256.

Shaaya, E. \& Ikan R.1978. The effectiveness of vegetable oils in the control of Callosobruchus maculutus. Institute for Technology and Storage of Agricultural Products, Department of Scientific Publications, Special Publication 216, Bet-Dagan, Israel. 39 pp.

Sherma, S.S. 1989. Review of Literature of the losses caused by material as grain protectants against insect pests of stored Callosobruchus species (Bruchidea: Coleopetra) during storage of pulses. Bull. Grain Technol. 22: 62-68.

Singh, S. R., Luse, R. A., Leuschrer, L. K. \& Nangju, D. 1978. Groundnut oil treatment for the control of
Callosobruchus maculatus (F.) during cowpea storage. J. stored Prod. Res. 14: 77-80.

Singh, S., Singal, S. K. \& Verma, A. N. 1990. Evaluation of some edible oils as protectants of chickpea seeds, Cicer arierinum L. against pulse beetle, Callosobruchus chinensis (L.) by preferential feeding method. In: Proc. $5^{\text {th }}$ Intl. Working Conf. Stored Prod. Protec. (Bordeaux, France, 1990) (eds. Fleurat-Lessard, F. \& Ducom, P.), pp.1715-1724.

Strong, R. G., Partida, G. J. \& Warner, D. N. 1968. Rearing stored product insects for laboratory studies, bean and cowpea weevil. J. Econ. Entomol. 61: 747-751.

Swella, G. B. \& Mushobozy, D. M. K. 2007. Evaluation of the Efficacy of Protectants against Cowpea Bruchids (Callosobruchus maculatus (F.)) on Cowpea Seeds (Vigna unguiculata (L.) Walp.). Plant Protect. Sci. 43: 68-72

Varma, B. K. \& Pandey, G. P. 1978. Treatment of stored green gram seed with edible oils for protection from C. macularus F. Indian J. Agric. Sci. 48: 72-75.

Manuscript received on 02.01.08, accepted on 24.01.08 